\title{
Re-Imagined Communities: The WTO Appellate Body and the Communitization of WTO Law
}

\author{
Geraldo Vidigal"
}

\section{Introduction}

The creation of the World Trade Organization (WTO), with its compulsory dispute settlement system, put WTO panels and the Appellate Body before a dilemma familiar to international adjudicators. Who do they adjudicate for, or, as Armin von Bogdandy and Ingo Venzke put it, in whose name do they adjudicate? ${ }^{1}$ To an extent, the range of options is the same contemplated by these authors: "Is it in the name of the parties to the concrete case, in the name of the international community, or in the name of a functional regime?" 2 . In the case of the WTO, this question acquires specific contours. Should WTO adjudicators aim to "secure a positive solution" to bilateral disputes, as Article 3.7 of the Dispute Settlement Understanding directs them to? Or should they seek first and foremost to "provid[e] security and predictability to the multilateral trading system", as suggested by DSU Article 3.2? Perhaps adjudicators should not pursue any particular goal, and act merely to "preserve the rights and obligations of Members" by "clarify[ing] the existing provisions" of WTO law, as the same Article 3.2 immediately adds?

These questions are not of merely academic interest. The answers have significant implications for the diplomats and lawyers appearing before panels and the Appellate Body, since they determine which arguments will count as persuasive before these adjudicators. More importantly, the answers shape the very character of the WTO legal system. Do the WTO Agreements create a mere multi-party contract, establishing bundles of bilateral legal relations that sub-groups of WTO Members remain free to shape and reshape on the basis of mutual consent? Or do they establish a

* Assistant Professor in Public International Law and International Trade Law, Amsterdam Centre for International Law, University of Amsterdam.

1 Von Bogdandy, A. and Venzke, I. (2014), In Whose Name? A Public Law Theory of International Adjudication. Oxford: Oxford University Press.

2 Ibid., 5. 
community, a common legal system whose rules can only be modified pursuant to the legal regime's collectively agreed procedures? And should the approach of panels and the Appellate Body to adjudication aim first and foremost at protecting the multilateral trading system, leaving to other specialized regimes the tasks of ensuring the protection of non-trade values such as environmental protection and human rights? Or may adjudicators take into account developments that take place in other international decision-making fora in their interpretation of WTO rights and obligations?

This Chapter argues that, by establishing a common institutional framework for the negotiation of trade relations, the WTO Agreements set up a community in the sense of a forum in which decisions can be made collectively and affect all Members. On the other hand, the early years of the WTO saw a controversy with respect to what the specific features of this community would be. Here, the direction given by the Appellate Body to the jurisprudence has been decisive. The Appellate Body's reading of the function of adjudication and the institutional provisions of the WTO Agreements has resulted in a significant communitization of WTO law. Contrary to what some expected, this communitization did not result in a trade-focused regime. Instead, the approach adopted by the Appellate Body to the WTO Agreements puts on equal footing "trade" and "nontrade" goals. Trade-restrictive and even discriminatory measures are permissible as long as they find a justification in a non-trade goal that, according to the Appellate Body, the community of Members has determined to be legitimate. Crucially, the Appellate Body infers the views of this community not only from decisions of WTO bodies but also from multilateral decisions and documents adopted in other fora that, in its view, express a consensus or a common understanding regarding interpretations and are apt to legitimize non-trade concerns as justification for governmental action.

Following this introduction, Section 2 discusses two approaches to rulemaking and adjudication, which we may call "societal-contractual" and "communitarian", arguing that the WTO Agreements themselves hesitate between the two. Section 3 demonstrates the adoption by the Appellate Body of a communitarian perspective, which has thwarted criticisms to the legitimacy of the WTO by incorporating non-trade values into the WTO Agreements and permitting a community-driven evolution of WTO rules. Section 4 discusses two problematic aspect of this approach. First, in the absence of a functioning legislator, the Appellate Body itself has become the arbiter of what constitutes the WTO community's views, an issue at the heart of the current Appellate Body crisis. Second, while the communitarian approach allows the incorporation of non-trade values that find a large 
degree of consensus within the community, it may hinder the evolution of trade rules on the basis of the societal-contractual method of agreements among some WTO Members only. Section 5 concludes.

\section{Society and Community in the WTO Regime}

\section{A. Society, Community and International Institutions}

The notions of "society" and "community" are borrowed from sociology, where they designate different models of relations between individuals and the group. ${ }^{3}$ The notion of society implies voluntary association between individuals which have (in theory) willingly consented to engage in relations with other individuals. Relations between individuals in a society are voluntary, and therefore contractual in character (the social contract). In theory, given the voluntary character of their association, individuals could ultimately reject the contract and retain their original freedom. At the very least, in an ideal type contract-based society, consenting individuals are free to negotiate any agreements between them, as long as they do not impinge on other individual's rights. The notion of a community, on the other hand, implies an organic relationship between the group and its component individuals, which are seen as members of an entity that takes precedence over them and without which their individual existence lacks meaning. Members of a community do not adhere to its norms individually but co-develop the community's norms in their interaction with other community members. Within an ideal-type community, there is no freedom of sets of individuals to negotiate their mutual relations: interpersonal relations are governed by community norms.

International law was shaped, in the $18^{\text {th }}$ and $19^{\text {th }}$ Centuries, following a contractual-societal logic that still finds reflection in many of its rules. Pursuant to this logic, states are sovereign entities whose existence precedes the existence of any norms constraining their conduct. ${ }^{4}$ While states are free to consent to restrictions on the exercise of their sovereignty,

3 Tönnies, F. (1935/2002), Community and Society = Gemeinschaft und Gesellschaft. Dover: Mineola. Tilman, R. (2004), "Ferdinand Tönnies, Thorstein Veblen and Karl Marx: From Community to Society and Back?", European Journal of the History of Economic Thought 11(4), 579-606.

4 The principle, expressed by the Permanent Court of International Justice (PCIJ) in Lotus, is that in the absence of consent "[r]estrictions upon the independence of States cannot... be presumed" (The case of the S.S. Lotus (France v. Turkey), Judg- 
sovereignty means that these restrictions are contractual in character: states remain free to leave these contractual engagements should they so wish and may, through mutual consent, modify between themselves any rule of purported general or multilateral application. The International Court of Justice traditionally operates under strong societal-contractual assumptions, recognizing the ability of pairs and groups of states to shape their mutual relations on the basis of consent. ${ }^{5}$

The narrative of an international society in which all obligations derive from consent is broken by two inter-related developments. First, the establishment of institutional fora of global reach, such as the United Nations institutions or the WTO, in which all states, or a significant number of them, may deliberate on the creation of new rules and norms, with such weight that there is little room left for those wishing to exercise their entitlement to individual rule-making outside the common normative framework. ${ }^{6}$ Second, the creation - largely within these institutions - of broad consensus among states with respect to certain structurally relevant norms, some of which are considered to bind all states and not to permit any derogation on the basis of inter-state consent. ${ }^{7}$ Whereas the latter norms are ordinarily considered to be the ones emanating from the "international community of States as a whole" 8 and therefore the most glaring example of the disruption to the societal-contractual model of rule-making, it is specific communities, created by treaties that establish legal regimes, creating institutional fora for deliberation and decision-making procedures, that have the largest potential to constrain states' ability to freely contract into and contract out of certain rules.

ment, 1927 PCIJ Series A No. 10, 18; ELSI (United States of America v. Italy), Judgment, ICJ Reports 1989, 15, 42).

5 See, e.g., Asylum (Colombia v. Peru), Judgment ICJ Reports 1950, 266, 277-278; Fisheries (United Kingdom v. Norway), Judgment, ICJ Reports 1951, 116, 131; Case concerning Right of Passage over Indian Territory (Portugal v. India) Merits, ICJ Reports 1960, 6, 39; Continental Shelf (Tunisia v. Libya), Revision and Interpretation, ICJ Reports 1985, 192, 219.

6 See, e.g., Legal Consequences for States of the Continued Presence of South Africa in Namibia (South West Africa) Notwithstanding Security Council Resolution 276 (1970), Advisory Opinion, ICJ Reports 1971, 16, 22; Whaling in the Antarctic Judgment (Australia v. Japan: New Zealand intervening), Judgment, ICJ Reports 2014, 226, 257, 270-271; Jurisdictional Immunities of the State (Germany v. Italy; Greece Intervening), ICJ Reports 2012, 99, 127, 147-148.

7 Vienna Convention on the Law of Treaties, Articles 53, 64.

8 Ibid. 


\section{B. Communitarian Institutions in the WTO Agreements}

With the conclusion of the Uruguay Round of trade negotiations in 1994, the various multilateral trade agreements previously signed by contracting parties to the General Agreement on Tariffs and Trade (GATT 1947) were merged into the Agreement Establishing the WTO (AEWTO), to which all other WTO Agreements are annexes. The negotiation principle of single undertaking adopted during the Uruguay Round, under which the WTO Agreements constitute a "package deal" that must be adhered to in its virtual entirety or not at all, was incorporated into the AEWTO. Unless otherwise specified, all WTO Agreements are "binding on all Members" ${ }^{9}$. Reservations are prohibited unless explicitly permitted. ${ }^{10}$

Besides creating a single set of substantive rules, the AEWTO established what it calls a "common institutional framework" for the conduct of trade relations, ${ }^{11}$ including an institutional structure and organs for collective decision-making. ${ }^{12}$ AEWTO Articles IX (Decision-Making) and X (Amendments) set up specific procedures for adopting, within WTO decision-making organs, modifications to and authoritative interpretations of the rights and obligations of Members. Although the effectiveness of this proto-legislature to address the demands of the trade regime has been questioned, ${ }^{13}$ the Ministerial Conference and subsidiary organs have adopted a number of waivers, ${ }^{14}$ and various consensus-based decisions, some of which expand significantly on previous obligations, such as the 2015 decision to prohibit

9 Agreement Establishing the WTO, Article II:2. The exception were the four plurilateral agreements, two of which expired in 1997.

10 Agreement Establishing the WTO, Article XVI:5.

11 Agreement Establishing the WTO, Article II:1.

12 Nottage, H. and Sebastian, T. (2006), "Giving Legal Effect to the Results of WTO Trade Negotiations: An Analysis of the Methods of Changing WTO Law”, Journal of International Economic Law 9(4), 989-1016.

13 Bartels, L. (2004), "The Separation of Powers in the WTO: How to Avoid Judicial Activism", International and Comparative Law Quarterly 53(4), 861-895; Ruiz Fabri, H. (2003), "La juridictionnalisation du règlement des litiges économiques entre États", Revue de l'arbitrage 3, 881-947; Von Bogdandy, A. (2001), "Law and Politics in the WTO - Strategies to Cope with a Deficient Relationship", Max Planck Yearbook of United Nations Law 5, 609-674.

14 See Feichtner, I. (2009), "The Waiver Power of the WTO: Opening the WTO for Political Debate on the Reconciliation of Competing Interests", European Journal of International Law 20(3), 615-645. 
export subsidies on agriculture. ${ }^{15}$ Although no formal authoritative interpretation has ever been adopted, in 2012 Members revised a plurilateral agreement (the Government Procurement Agreement), ${ }^{16}$ in 2013 they agreed to a wholly new agreement (the Trade Facilitation Agreement), ${ }^{17}$ and in 2017 the first amendment (to the Agreement on Trade-Related Aspects of Intellectual Property Rights) came into force. ${ }^{18}$ At the margins, at least, WTO Members are able to create new rules and modify existing ones.

A core aspect of the WTO's institutional framework is its Dispute Settlement Understanding (DSU). Under the DSU, any WTO Member may bring a claim against any other Member with respect to any "measures affecting the operation of any covered agreement"19. The DSU all but ensures that a complainant can obtain a report which, once adopted, must be complied with by a Member found in breach. ${ }^{20}$ To enforce reports, the DSU establishes a system of collective political surveillance of implementation by the WTO Membership ${ }^{21}$ and, in case of persistent non-compliance, features a fall-back mechanism permitting the complainant to adopt trade retaliation against the recalcitrant state. ${ }^{22}$

\section{Communitarian Institutions and Bilateral Enforcement}

The existence of a dispute settlement system from which parties cannot withdraw provides the WTO with a strong communitarian element not usually found in international organizations. The DSU allows any WTO

15 WTO Ministerial Decision, “Export Competition”, 19 December 2015 (WT/L/ 980). WTO organs can also adopt majority decisions, although these remain exceptional. Decision of the General Council on the accession of Ecuador (adopted in spite of the opposition of Peru), WT/ACC/ECU/5 (22 August 1995).

16 Revised Government Procurement Agreement, agreed 30 March 2012 (GPA/113), entered into force 6 April 2014.

17 Agreement on Trade Facilitation, General Council Decision of 28 November 2014 (WT/L/940), entered into force 22 February 2017.

18 Amendment to the TRIPS Agreement, 6 December 2005 (WT/L/641), took effect 23 January 2017.

19 DSU, Article 4.2.

20 DSU, Article 21.1. The current deadlock over Appellate Body appointments means that, since December 2019, the ability of Members to obtain a report has been compromised.

21 DSU, Article 21.6.

22 DSU, Article 22. 
Members to obtain from an adjudicator an interpretation of another Member's WTO obligations. At the same time, there are no community organs tasked with enforcing the WTO Agreements, meaning that the agreements are only enforced to the extent that a Member takes issues with a violation. Additionally, despite trade retaliation for persistent non-compliance being collectively authorized, the only Members allowed to apply retaliation are those that have brought the complaint. The design of WTO dispute settlement subjects the WTO's institutionalized enforcement mechanism to the bilateral relations between the parties to a dispute.

In terms of law-making, the WTO Agreements not only establish decision-making procedures for the creation of new norms but feature two significant prohibitions on "contracting out". Article 11.1(b) of the Agreement on Safeguards prohibits WTO Members from agreeing to exportrestrictive measures outside of WTO rules, including "voluntary export restraints, orderly marketing arrangements or any other similar measures". It specifies that the prohibition covers both actions taken by a single Member and "actions under agreements, arrangements and understandings entered into by two or more Members". This prohibition constitutes precisely the sort of collectively-determined restriction on contractual freedom that characterizes a community. It prevents resort to so-called "grey area" measures, bilateral arrangements used prior to the creation of the WTO to circumvent GATT prohibitions on discriminatory and traderestrictive measures on imports. ${ }^{23}$ Authorization of trade-restrictions not warranted by WTO law must be given by the whole community, in the form of a waiver.

Additionally, Article 3(5) of the DSU restricts the ability of parties to a dispute to agree to a mutually agreed solution that results in a violation of the WTO rules. It provides: "All solutions to matters formally raised under the consultation and dispute settlement provisions of the covered agreements, including arbitration awards, shall be consistent with those agreements and shall not nullify or impair benefits accruing to any Member under those agreements, nor impede the attainment of any objective of those agreements."

Article 3(5) applies to situations in which a matter is "formally raised" before the WTO dispute settlement organs. However, the DSU covers all "situations in which a Member considers that any benefits accruing to it

23 GATT Secretariat, “'Grey-Area' Measures - Background Note by the Secretariat”, 16 September 1987 (MTN.GNG/NG9/W/6). 
directly or indirectly under the covered agreements are being impaired" 24 . It therefore suffices for a Member to decide to bring a matter formally before the Dispute Settlement Body for Article 3(5) to apply, requiring "[a]ll solutions" to be consistent with the WTO Agreements. Article 3(7) provides that "solution[s] mutually acceptable to the parties to a dispute" are "to be preferred", as long as these solutions are "consistent with the covered agreements", and Article 22(1) provides that "full implementation of a recommendation to bring a measure into conformity with the covered agreements" is to be "preferred" to compensation of an aggrieved Member by the violator.

The language of "preference" is not unequivocal. Article 22(8), which governs the time after a dispute is over, presents as alternative possibilities the removal of the WTO-inconsistent measure, the end of the nullification or impairment caused by the measure, and the attainment of "a mutually satisfactory solution". While substantive provisions prohibit a violator from relying on the societal-contractual structure of the WTO to obtain the agreement of an aggrieved party to trade-restrictive measures, the bilateral structure of WTO dispute settlement, by which each Member may "exercis $[\mathrm{e}]$ its judgment" as to whether bringing a dispute "would be fruitful", 25 allows Members to tolerate non-compliance as well as to agree to bilateral arrangements that permit the persistence of measures found to be inconsistent with WTO rules. The WTO Agreements therefore feature some restrictions on the ability of Members to "contract out" of WTO rules, but entrust individual states with enforcing WTO rules and entering into understandings to settle disputes. The enforcement of the communitybacked rules depends on bilateral relations between the Members.

\section{The Appellate Body and the Establishment of a WTO Community}

\section{A. The Prospect of a Trade-Focused Community}

In the early years of the WTO, it was unclear what effects the WTO's institutional structure would have for the continued ability of WTO Members to enter into "inter se" agreements - bilateral or "minilateral" agreements modifying WTO rules among some Members only - and have these agreements acknowledged by WTO adjudicators. Joost Pauwelyn argued that, in

24 DSU, Article 3.3.

25 DSU, Article 3.10 . 
case norms created outside the WTO system conflicted with WTO rules, these conflicts should be solved by recourse to the rules governing conflicting treaties in Articles 30, 41 and 59 of the Vienna Convention on the Law of Treaties. These rules have strong societal-contractual features, essentially permitting states to renegotiate their legal relations through inter se agreements as long as they do not interfere with the rights of third states. Pauwelyn summarized these rules as "the 'holy trinity' of (i) contractual freedom of states; (ii) pacta sunt servanda; and (iii) pacta tertiis" 26 .

If this societal-contractual view were to prevail, panels and the Appellate Body adjudicating WTO disputes would be required to examine all the international agreements between the parties to a dispute and determine which rules prevail. In case they found the non-WTO agreement to prevail, they would then apply the norm contained in the non-WTO agreement rather than the WTO rule. ${ }^{27}$ In other words, the WTO Agreements would not have established a community able to affect the freedom of WTO Members to enter into conflicting engagements and have them enforced within WTO adjudication. As Erich Vranes explains, this approach consists, in large measure, in "a restatement of the rules of general international law: inter se modifications of the WTO treaty are permissible in line with the principles of international law"28. In other words, state sovereignty, or their rule-making freedom under the societal-contractual assumptions of general international law, should prevail over communitarian provisions of the WTO Agreements.

The opposite view held that, while Members remained sovereign to sign any trade agreements, the provisions of the DSU governing adjudication did prevent panels and the Appellate Body from giving effect to norms established outside the WTO Agreements. Article 3.2 of the DSU provides that the WTO dispute settlement system serves to "preserve the rights and obligations of Members under the covered agreements, and to clarify the existing provisions of those agreements". Article 7.1 requires panels, unless

26 Pauwelyn, J. (2003), Conflicts of Norms in Public International Law: How WTO Law Relates to Other Rules of International Law. Cambridge: Cambridge University Press, 436.

27 Pauwelyn, J. (2003), "A Typology of Multilateral Treaty Obligations: Are WTO Obligations Bilateral or Collective in Nature?", European Journal of International Law 14(5), 907-951.

28 Vranes, E. (2008), “Comments on Joost Pauwelyn's Paper: 'How to Win a WTO Dispute Based on Non-WTO Law?” In: S. Griller (ed.), At the Crossroads: the World Trading System and the Doha Round. Wien / NewYork: Springer, 83-100, 98. See also Vranes, E. (2006), “The Definition of 'Norm Conflict' in International Law and Legal Theory", European Journal of International Law 17(2), 395-418. 
otherwise agreed by the parties, to examine disputes brought to the Dispute Settlement Body in light of the WTO Agreements only. And Articles 3.2 and 19.2 preclude panels and the Appellate Body from "add[ing] to or diminish[ing] the rights and obligations provided in the [WTO] covered agreements".

The arguments used to justify this deviation from the societal-contractual assumptions regarded not the substantive WTO rules, but the institutional provisions governing dispute settlement. Lorand Bartels proposed that, in case of conflict, DSU Articles 3.2 and 19.2 would ensure the primacy of WTO rules "in an indirect manner" by requiring adjudicators to consider the WTO rule as the "applicable rule" in the face of a conflicting external rule. ${ }^{29}$ Gabrielle Marceau argued that an assessment of the relations established by the WTO Agreements should take into account "both the substantive and the procedural aspects of this relationship, i.e. the normative and jurisdictional dimensions" 30 . Panels and the Appellate Body would lack the "constitutional capacity to reach a conclusion that would lead de facto to an amendment of the WTO treaty" ${ }^{31}$. In case of a direct conflict that could not be avoided through interpretation, panels and the Appellate Body might recognize that a WTO obligation had been superseded. But these organs could at most issue a declaratory statement, refraining from adopting any rulings, findings or recommendations that would contradict their obligation not to add to or diminish the WTO rights and obligations of Members. ${ }^{32}$

Thus, this argument against "contracting out" of WTO rules does not amount to the claim that state sovereignty should be rejected, but instead argues that states would be able to employ, and in the case of the WTO had employed, their sovereignty to establish communitarian normative systems shielded from the general rules governing rule-making and rule-modification. In other words, through the institutional provisions governing rulemaking and the tasks of panels and the Appellate Body, WTO Members had established a separate legal regime, a legal community with its own collectively agreed norms enforceable by these specialized adjudicators.

29 Bartels, L. (2001), "Applicable Law in WTO Dispute Settlement Proceedings”, Journal of World Trade 35(3), 499-519, 507.

30 Marceau, G. (2001), "Conflicts of Norms and Conflicts of Jurisdiction - The Relationship between the WTO Agreement and MEAs and other Treaties", Journal of World Trade 35(6), 1081-1131, 1082.

31 Ibid., 1095.

32 Ibid., 1130. 
These same norms could determine the extent to which modifications through external rule-making could impact the internal WTO regime.

Beyond its technical aspects, this debate was linked to concerns about a functional differentiation between the WTO's "trade regime" and other regimes protecting non-trade concerns, such as environmental protection or human rights. A communitarian WTO legal system, the reasoning went, would result in trade obligations prevailing over non-trade obligations. While these other concerns are protected in their own specialized regimes, none of these regimes can rely on the combination of nearly global participation, compulsory adjudication and enforcement through trade retaliation that makes the WTO system unique. If the "WTO community" were to be the community of specialized trade negotiators, deciding on the basis of the purely economic concerns negotiators sought to protect when negotiating trade agreements, leaving non-WTO rules outside the scope of adjudication could lead to the quasi-automatic condemnation before WTO panels of measures taken by WTO Members justified by norms developed in forums other than the WTO to protect non-economic concerns.

At the same time, rejecting the communitarian view would have implied a (re-)bilateralization of WTO legal relations. Any idea of a coherent WTO legal system would be lost in favour of a societal-contractual system in which each pair or sub-group of Members would be subject to particular legal relations. Pauwelyn noted that "WTO rules would apply differently to different WTO members depending on whether or not they have accepted other non-WTO rule", but considered this a means to avoid a more problematic scenario in which WTO adjudicators, finding themselves unable to take into account non-WTO rules, would make decisions purely on the basis of WTO rules and have the trade regime prevail over legal regimes that seek to protect non-trade values. ${ }^{33}$

These concerns appeared warranted by two disputes on environmental measures, one taking place immediately before, the other immediately after the entry into force of the WTO Agreements. In 1991, the GATT 1947 panel in US - Tuna examined a US measure prohibiting the importation of tuna products unless the tuna was caught using a mechanism to prevent the incidental capture of dolphins. The panel held that allowing this measure to be justified under GATT Article XX could threaten the entire "multilateral framework for trade" established by the GATT, ${ }^{34}$ allowing a party

33 Pauwelyn, supra note 26, 476.

34 GATT, Panel Report, US - Restrictions on Imports of Tuna (DS21/R - 39S/155), 3 September 1991, para. 5.27. 
to "unilaterally determine the conservation policies" of other parties..$^{35}$ This was followed, in 1999, by the WTO panel report in US - Shrimp, a dispute concerning a US prohibition on the importation of shrimp caught without a system for releasing turtles caught as by-catch. Following the GATT panel in US - Tuna, the WTO panel in US - Shrimp found that no WTO exception allowed the US to restrict trade in the pursuit of environmental goals outside US territory. Allowing a WTO Member to "condition[] access to its market for a given product upon the adoption by the exporting Members of certain policies, including conservation policies", the panel reasoned, would threaten the integrity of the multilateral trading system. ${ }^{36}$ The reasoning used by these panels, grounded in the presumed objective of the WTO Agreements to promote trade liberalization and reject all discrimination, corroborated the narrative according to which the WTO Agreements established a trade-focused community, with WTO adjudicators privileging trade liberalization over the protection of non-trade concerns. It was the Appellate Body's intervention that challenged this narrative.

\section{B. From Trade Regime to Text Regime: The Appellate Body's Intervention in US - Shrimp and Beyond}

Despite its high profile, $U S$ - Shrimp was not the first dispute in which the conflict between trade and non-trade objectives appeared before WTO adjudicators. In its first report, in US - Gasoline, the Appellate Body famously declared that the WTO Agreements were "not to be read in clinical isolation from public international law" 37 . The US - Gasoline report also marked the first time the Appellate Body set aside a panel's tradefocused view of the WTO Agreements. ${ }^{38}$ Instead, the Appellate Body developed what could be called a "text-centered" view of the WTO Agreements, putting on equal footing all the provisions of the WTO Agreements without making a distinction between trade and non-trade objectives. It

35 Ibid., para. 5.32 .

36 WTO, Panel Report, US - Shrimp, at 7.45, 7.61.

37 Appellate Body Report, US - Gasoline, 17.

38 Panel Report, US - Gasoline, para. 6.40. The panel linked the consistency of the US measure with Article III:4 to its compatibility with Article XX(g) ("affording treatment of imported gasoline consistent with its Article III:4 obligations would not in any way hinder the United States in its pursuit of its conservation policies under the Gasoline Rule"). 
found that the "purposes and objects" of the GATT included both "affirmative commitments", prohibiting discrimination and trade-restrictive measures, and the protection of the legitimate "policies and interests", made possible by the general exceptions of Article XX. ${ }^{39}$

The consequences of this shift in focus would become clear in US Shrimp. The Appellate Body labelled the panel's reasoning, that Article XX simply could not allow a Member to condition market access on the adoption of environmental measures, "an a priori test" developed without a textual basis, stating that such a test would make "most, if not all", the GATT exceptions that allow the adoption of legitimate measures "inutile". ${ }^{40} \mathrm{Cru}$ cially, the Appellate Body reversed the panel's statements of principle with respect to the object and purpose of the WTO Agreements, emphasizing instead that the WTO Agreements explicitly recognized "the objective of sustainable development" ${ }^{41}$. Thus, the Appellate Body considered the conservation objective pursued by the US measure not as an external interference from the environmental regime into the WTO regime, a "threat to the multilateral trading system" as the panel put it. ${ }^{42}$ Instead, the Appellate Body incorporated the objective of environmental conservation into the WTO regime itself, expanding it from a trade-focused regime into a comprehensive legal regime that allows, and even encourages, ${ }^{43}$ Members to pursue their public policy goals.

This logic, whereby "non-trade values" are not an external interference but an integral part of the WTO regime, was applied in subsequent cases in which the Appellate Body was confronted with a possible conflict between WTO obligations and supposedly external values that would have required Members to deviate from their WTO obligations. In EC - Hormones, confronted with the request that it adapt provisions of the SPS Agreement to the precautionary principle, the Appellate Body stated that the precautionary principle "finds reflection in" the various provisions of the SPS Agreement that allow Members to adopt SPS measures without full scientific evidence, so that there was no need to refer to external normative sources. ${ }^{44}$ In EC - Tariff Preferences, the Appellate Body reversed the panel's

39 Appellate Body Report, US - Gasoline, 18.

40 Appellate Body Report, US - Shrimp, para. 121.

41 Ibid., para. 129.

42 Panel Report, US - Shrimp, para. 7.61.

43 Appellate Body Report, US - Shrimp, para. 185 ("We have not decided that the sovereign nations that are Members of the WTO cannot adopt effective measures to protect endangered species, such as sea turtles. Clearly, they can and should.”).

44 Appellate Body Report, EC - Hormones, paras. 120-124. 
statement that the objective of trade liberalization was more relevant to the interpretation of the Enabling Clause than the objectives of promoting the trade of developing countries and fulfilling their development needs..$^{45}$ Instead, it found that these objectives coexisted on an equal footing, permitting the adoption of programmes that discriminate between developing countries on the basis of their development needs. ${ }^{46}$ And, in US - Clove Cigarettes, the Appellate Body found that the obligations of the Agreement on Technical Barriers to Trade, which could limit Members' ability to regulate if such regulations restrict international trade, had to be interpreted in light of a recital of its preamble, which it labelled an "explicit recognition of Members' right to regulate in order to pursue certain legitimate objectives" 47 .

\section{Legitimate Non-Trade Values beyond the Four Corners: the Delegation of Authority and the Voices of the International Community}

The Appellate Body's interventions have expanded the WTO legal system from a trade-focused regime into a broader legal regime in which "trade goals", i.e. the objectives of trade liberalization and non-discrimination, do not take precedence over but coexist with other goals. A legitimate objective, such as environmental conservation, the protection of consumer health or the fulfilment of development needs, may justify the adoption of trade-restrictive measures as well as discrimination between products, producers or countries.

How precisely these permitted grounds for discrimination are incorporated into the interpretation of WTO rules depends on the provision being examined, and the Appellate Body itself has provided different answers at different times. Under GATT and GATS, besides the obvious moment within the interpretative exercise for the consideration of legitimate grounds for the adoption of trade-restrictive or discriminatory measures (the General Exceptions of Article XX GATT/XIV GATS), the Appellate Body has occasionally found that legitimate grounds for distinguishing between products or services could justify not treating the imported product or service as "like" other products that otherwise compete in the same

45 Appellate Body Report, EC - Tariff Preferences, paras. 138, 170.

46 Ibid., para. 173.

47 Appellate Body Report, US - Clove Cigarettes, para. 94. 
market. ${ }^{48}$ In Dominican Republic - Cigarettes, the Appellate Body also found that a measure that gives domestic products a competitive advantage over like imported products might not constitute less favourable treatment if the detrimental effect on imported products could be "explained by factors or circumstances unrelated to the foreign origin of the product" 4 . With respect to the Agreement on Technical Barriers to Trade, which does not feature an equivalent to GATT Article XX, the Appellate Body determined that the very finding of less favourable treatment involves an assessment of whether a measure's detrimental effects on imports are based on a "legitimate regulatory distinction" 50 .

Expanding the possibility of fulfilling non-trade objectives opens the question of which policy objectives and which regulatory distinctions are "legitimate", permitting Members to adopt otherwise WTO-inconsistent measures. In this regard, the Appellate Body operated another crucial shift in the jurisprudence, "opening" WTO rules to inputs not only from WTO bodies but also from organs of the international community more broadly.

This shift first took place, once more, in US - Shrimp. The Appellate Body held that GATT Article XX(g) justified measures directed at the conservation of living resources, grounding this interpretation not only on the preamble to the WTO Agreement but also on a series of treaties, resolutions, declarations and reports signed or issued in connection with various international organizations and institutions. These documents, which did not in themselves create legal rights and obligations between the parties to the US - Shrimp dispute, were mentioned because they represented an "acknowledgement by the international community of the importance of concerted bilateral or multilateral action to protect living natural resources" 51 . The "community determination" that shaped the Appellate Body's interpretation of a provision of WTO law was not a decision adopted by the WTO Membership following a procedure established in the WTO Agreements but the diffuse recognition, in various documents purportedly conveying the views of the international community, of a nontrade concern justifying the adoption of the US measure.

48 Appellate Body Reports, EC - Asbestos, para. 130; Argentina - Financial Services, paras $6.64,6.70$.

49 Appellate Body Report, Dominican Republic - Cigarettes, para. 96 (although the reason in this case was "the market share of the importer", the choice of words opens the door for other "factors or circumstances" to justify detrimental impact on foreign products).

50 Appellate Body Report, US - Clove Cigarettes, paras. 174, 181.

51 Appellate Body Report, US - Shrimp, para. 131. 
Other decisions of the Appellate Body demonstrate a similar willingness to acknowledge the possibility for Members to enter into understandings outside the framework of the agreement being interpreted, influencing decisively the interpretation of WTO law. In US - Cloves, the Appellate Body noted that the assessment of what counts as a legitimate objective justifying detrimental effects on imported products could be done not only in light of the objectives explicitly recognized in the TBT Agreement but also by taking into account other objectives recognized in other WTO Agreements. ${ }^{52}$ In EC - Tariff Preferences, the Appellate Body found that legitimate grounds for discrimination between developing countries in systems of preferences could be found in " $[\mathrm{b}]$ road-based recognition of a particular need, set out in the WTO Agreement or in multilateral instruments adopted by international organizations" 53 . In EC-Hormones, the Appellate Body found that a Member would be able to justify adopting a measure not ordinarily permitted by the SPS Agreement if there was a "clear textual directive" from the Membership authorizing it, but did not expand on who would be able to issue this directive. ${ }^{54}$

In EC-Hormones, while it is conceivable that only the organs specifically authorized to produce standards for food safety in the SPS Agreement ${ }^{55}$ would be able to issue a textual directive affecting the outcome of the dispute, possibilities of collective "weighing in" are significantly broader. The notion that the formal procedure of Article IX:2 is required for Members to influence treaty interpretation was set aside in US - Clove Cigarettes and US - Tuna II. In the former, while recognizing that the Doha Ministerial Decision did not constitute an authoritative interpretation of the WTO Agreements (in the sense of AEWTO Article IX:2), the Appellate Body found that it constituted a subsequent agreement on the interpretation of WTO law by the Membership in the sense of Article 31(3)(a) of the Vienna Convention on the Law of Treaties. ${ }^{56}$ In US - Tuna II, the Appellate Body found that it was sufficient for a decision to be adopted "subsequent" to the WTO Agreements and to "express an agreement between Members on the interpretation or application of a provision of WTO law" 57 for it to

52 Appellate Body Report, US - Tuna II, para. 313.

53 Appellate Body Report, EC - Tariff Preferences, para. 163.

54 Ibid.

55 See SPS Agreement, Annex A, para. 3.

56 Appellate Body Report, US - Clove Cigarettes, para. 262.

57 Appellate Body Report, US - Tuna II, para 372. 
constitute a subsequent agreement, to be "read into the treaty for purposes of its interpretation" 58 .

Panels have now caught up with the interpretative scheme applied by the Appellate Body and are willing to take into account multilateral nontrade documents to justify interpretations of WTO norms. In Brazil - Taxation, pointing to the United Nation's Millennium Development Goals, the panel recognized the legitimacy under Article XX(a) of Brazil's stated objective of bridging the "digital divide", even though characteracterizing this objective as part of "public morals" seems like a long shot, on the grounds that Brazil's stated concern was "internationally recognised as an issue confronting developing countries" ${ }^{9}$ In Australia - Tobacco Plain Packaging, the panel accorded significant weight (without explaining its legal grounds for doing so) to the fact that Australia "pursue[d] its domestic public health objective in line with its commitments' under the Framework Convention on Tobacco Control", which the panel highlighted "ha[d] been ratified by 180 countries".60 Both the existence of the convention and its broad ratification were found to be key to demonstrate why it would provide grounds for an interpretation of WTO rules permitting a Member to adopt a measure that could otherwise be found to impinge on other Members' rights.

\section{Delegated Authority and the Voice of the International Community}

From this jurisprudence, it appears that the "delegated authority" for influencing WTO interpretation is exercised effectively within multilateral fora and institutions, whether within or outside the WTO. Without multilateral or institutional support, on the other hand, Members may have a hard time influencing interpretations of WTO Agreements.

In the absence of institutions, Members have difficulty demonstrating the existence of multilateral consensus able to influence the interpretation of WTO rules. In Chile - Price Band System, the Appellate Body noted that a "discernible pattern of acts or pronouncements implying an agreement among WTO Members" on the interpretation of a provision would amount to subsequent practice, decisively affecting interpretation under

58 Appellate Body Report, US - Clove Cigarettes, para. 269.

59 Panel Report, Brazil - Taxation, paras. 7. 563, 7.565.

60 Panel Report, Australia - Plain Packaging, para. 7.2596. 
Article 31(3)(b) of the Vienna Convention on the Law of Treaties. ${ }^{61}$ However, contrary to what is the case for subsequent agreements, demonstrating the "concordant, common and consistent" 62 practice required for this influence to take place is difficult. In none of the four disputes in which a party invoked subsequent practice did the Appellate Body consider that the relevant practice attained the degree of commonality required to influence interpretation. ${ }^{63}$

Similarly, non-multilateral agreements have been found to be irrelevant for the interpretation of WTO rules. In EC - Poultry, the Appellate Body refused to accord interpretative value to a bilateral understanding between the parties even though it had been approved by the GATT Contracting Parties. ${ }^{64}$ In Brazil - Tyres, ${ }^{65}$ Mexico - Soft Drinks, ${ }^{66}$ EC - Large Civil Aircraft $^{67}$ and Peru - Agricultural Products, ${ }^{68}$ the Appellate Body rejected claims that inter se agreements could per se influence either the rights and obligations of the disputing parties or the interpretation of the WTO rules in dispute.

Thus, following the guidance provided by the Appellate Body, WTO adjudicators have gotten into the habit of seeking authority or justifiable grounds for adopting a measure in principle contrary to WTO rules in documents that can credibly claim to express the view of the international community, either because they are adhered to by a vast number of WTO Members or because they emanate from an organization or institution to which a vast amount of Members are parties. This in turn creates an incentive for Members wishing to make an impact on the interpretation of WTO law to work towards building institutions and fora with legitimacy to make decisions in the name of the whole community, rather than agreeing to norms and interpretations individually or among small groups of Members, i.e. "minilaterally". The communitization of WTO rules therefore drives Members to develop other norms within community fora rather than in minilateral ones.

61 Appellate Body Report, Chile - Price Band System, para. 214.

62 Appellate Body Report, Japan - Alcoholic Beverages II, 13.

63 Appellate Body Reports, Japan - Alcoholic Beverages II, 13; EC - Computer Equipment, para 95; Chile - Price Band System, para. 214; US - Gambling, para 193.

64 Appellate Body Report, EC - Poultry, WT/DS69/AB/R, paras. 79-81.

65 Appellate Body Report, Brazil - Tyres, WT/DS332/AB/R, para 228.

66 Appellate Body Report, Mexico - Soft Drinks, WT/DS308/AB/R, para. 68.

67 Appellate Body Report, EC - Large Civil Aircraft, para. 845.

68 Appellate Body Report, Peru - Agricultural Products, para. 5.106. 


\section{The Promise and Threats of Communitization}

\section{A. Communitization as a Legitimacy-Enhancing Approach}

The Appellate Body's version of communitization, which includes the shift from a trade-focused regime to a text-focused regime open to influences that emanate from decisions representing the "community view", has permitted the WTO to deflect much of the early criticism directed at the organization. The Appellate Body's approach to interpretation, which put trade and non-trade goals on an equal footing, has thwarted fears that WTO rules would prevent Members from adopting measures to safeguard important societal values. Significantly, this approach has managed to do so while preserving the integrity of WTO law, that is, without permitting the fragmentation of the WTO Agreements into bundles of bilateral legal relations, each governed by a specific set of rules or by rules interpreted according to the specific relations between the parties to a dispute. As the Appellate Body put it in EC - Large Civil Aircraft, it sees its task as "ensuring a consistent and harmonious approach to the interpretation of WTO law among all WTO Members" ${ }^{9}$.

This approach has ensured the "security and predictability"70 of the WTO legal system and allowed the WTO to remain the "common institutional framework" 71 for decisions regarding multilateral trade relations. It has also secured the legitimacy of the WTO system vis-à-vis groups that would find it unacceptable for an international trade organization to prevent Members from adopting measures aimed at fulfilling legitimate social goals enshrined in documents emanating from the organs and bodies that speak in the name of the international community. ${ }^{72}$

On the other hand, the communitizing approach leads to two important consequences that have also raised questions regarding the legitimacy of the WTO. First, the focus on the interpretative unity of WTO law has led the Appellate Body to ascribe to its own reports an interpretative value that does not emerge clearly from the DSU. Second, the impossibility for Members to shape their own bilateral relations without multilateral

69 Appellate Body Report, EC - Large Civil Aircraft, para. 845.

70 DSU, Article 3.2.

71 AEWTO, Article II:1.

72 Weiler, J.H.H. (2001), "The Rule of Lawyers and the Ethos of Diplomats: Reflections on the Internal and External Legitimacy of WTO Dispute Settlement”, Journal of World Trade 35(2), 191-207. 
approval may still backfire, if non-trade values are enshrined in bilateral or minilateral rather than multilateral documents.

\section{B. The Communitization of Interpretations}

While the Appellate Body's approach to interpretation in principle opens the interpretation of WTO rules to input from organs and documents representing the voice of the Membership or the international community more broadly, it is simultaneously true that it has concentrated interpretative power - including the power to determine to what extent external input can be taken into account - in the hands of the Appellate Body itself.

In a sense, this is a consequence of the institutional structure of the WTO. The Appellate Body is tasked with reviewing "issues of law" and "legal interpretations" in panel reports. ${ }^{73}$ The DSU ascribes to the dispute settlement system the function of providing "security and predictability" to the multilateral trading system, ${ }^{74}$ something which arguably requires consistency among decisions. If it is to provide security and predictability to legal interpretations, the Appellate Body must necessarily seek interpretative consistency in its reports. Since every Member may ultimately obtain an interpretation from the Appellate Body that both itself and the respondent must unconditionally accept, any interpretation from an Appellate Body striving for consistency will eventually become the dominant interpretation. In this sense, the Appellate Body will always centralize WTO interpretations and determine what the "community interpretation" is. ${ }^{75}$

However, the Appellate Body has inferred from these institutional provisions an explicit hierarchy whereby its own reports become not just authoritative views but sources of law, not only guiding its own future decisions but also binding future panels and Members. In response to the statement of the panel in US - Stainless Steel (Mexico), that it "felt compelled to depart from the Appellate Body's approach"76, the Appellate Body stated that the DSU created a "hierarchical structure" between itself and panels. Only "cogent reasons" could justify a panel "depart[ing] from

73 DSU, Article 14.6.

74 DSU, Article 3.2.

75 See Stone Sweet, A. \& Brunell, T.L. (2013), “Trustee Courts and the Judicialization of International Regimes: The Politics of Majoritarian Activism in the European Convention on Human Rights, the European Union, and the World Trade Organization", Journal of Law and Courts 1(1), 61-88.

76 Panel Report, US - Stainless Steel (Mexico) (WT/DS344/R), para 7.106. 
well-established Appellate Body jurisprudence"77. In a subsequent case, US - Continued Zeroing, one Appellate Body member stated that since the Appellate Body had "spoken definitively" on zeroing, this statement "must prevail" in subsequent disputes. ${ }^{78}$

Thus, while the Appellate Body has made important steps towards expanding the legislative function in the "WTO community", it has also made itself - in the absence of agreement among the Members - the voice of this community, able to speak "definitively" where Members disagree. Since any attempt to reverse an interpretation by the Appellate Body requires the assent of the Member that requested adjudication in the first place, the "consistent and harmonious" interpretation of WTO law all too often boils down to the interpretation of WTO law determined by the Appellate Body. This centralization of interpretations in the hands of adjudicators constitutes a threat to the legitimacy of the Appellate Body - as seen in the present crisis on appointments - and, ultimately, to that of the organization itself.

\section{Communitization and the Challenge of Value-Laden Regionalism}

Given the difficulties of advancing at the multilateral stage, bilateral and minilateral trade agreements among small numbers of countries have grown significantly in importance and complexity since the WTO Agreements were negotiated. In late 2018, the 11-party Comprehensive and Progressive Trans-Pacific Partnership (CPTPP) entered into force. ${ }^{79}$ Together with the Comprehensive Economic and Trade Agreement (CETA) between Canada and the European Union, which entered into force provisionally in September 2017, the finalized EU-Japan Economic Partnership Agreement, and the 2018 United States-Mexico-Canada Agreement, CPTPP marks a new stage in international economic dealings - an era of "mega-regional" agreements.

Mega-regionals are not necessarily new with regard to their scope. The range of topics governed by trade agreements has been expanding markedly since the early 2000s, with "Free Trade Agreements 2.0" establishing comprehensive disciplines for the regulation of themes such as intellec-

77 Appellate Body Report, US - Stainless Steel (Mexico) (WT/DS344/AB/R), paras. 304-313.

78 Ibid.

79 Hutton, J. (2018), “Trans-Pacific trade pact will go into force next month", Straits Times, 1 November. 
tual property rights, financial markets, and electronic commerce, and including provisions relating to environmental regulation, labour rights and fisheries. Up until 2018, however, and with the exception of intraregional agreements (the North American Free Trade Agreement and the European Union), FTAs 2.0 were restricted to the relations between the largest economies and their smaller trade partners. Relations between the world's largest economies across economic regions still took place essentially on WTO terms. The entry into force of mega-regionals changes that, with the result that significant portions of global trade will be governed by bilateral and minilateral agreements.

The communitization of the WTO legal system has prevented the use of FTAs to affect WTO legal relations, with the Appellate Body having acted decisively to prevent FTAs from being used to justify new trade barriers among the participants, new trade barriers vis-à-vis third WTO Members, and discrimination in favour of trade partners beyond the strict terms of Article XXIV. While so far this stance has strengthened the multilateral trading system by preventing the fragmentation of the WTO legal system, the same inflexibility may become a handicap once FTAs are both far wider in scope than WTO rules and a means of regulating relations between large Members (who still constitute the vast majority of the users of the WTO dispute settlement procedures).

The rejection of bilateralization of trade relations may become particularly problematic once the social or environmental chapters of FTAs 2.0 are invoked, either to bar trade in products whose production process or characteristics of production disregard social and environmental requirements or to justify trade barriers adopted in response to failure to comply with social and environmental clauses. While the Appellate Body's communitizing stance would permit justifying discrimination against a Member that is backed by a decision of a multilateral institution, such as the International Labour Organization or the Convention on International Trade in Endangered Species of Wild Fauna and Flora, the reasoning employed by the Appellate Body in Mexico - Soft Drinks and Peru - Agricultural Products would lead a panel to reject a trade-restrictive measure adopted in response to a failure to comply with environmental or labour provisions agreed on a bilateral or minilateral basis. The Appellate Body will then have to choose between its communitizing stance, which should lead it to reject restrictions based on bilateral deals, and its legitimacy-boosting stance of accepting that trade obligations should not prevent Members from adopting restrictions that fulfil non-trade objectives. 


\section{Conclusion}

The transformation of the GATT regime into the World Trade Organization brought to the fore two dilemmas for the then new organization. First, to what extent did the WTO Agreements break with the societal-contractual model of trade relations that allowed GATT Contracting Parties to renegotiate agreements among them, and replace it with a communitarian system that requires collective approval for deviations from the general rules? Second, to the extent that the WTO regime is communitarian in nature, is this a trade-focused community or a branch of a broader international communitarian structure, capable of absorbing norms made by the international community outside the "four corners" of the WTO?

Through its jurisprudence, the Appellate Body provided answers to these questions through two significant shifts in WTO jurisprudence. First, the traditional approach to interpretation employed by GATT panels, which privileged an assessment of the presumed liberalizing intention of trade negotiators, was replaced with an assessment based on the text of the agreements and agnostic with regard to their overall purpose, recognizing different "purposes and objects" in different provisions of the WTO Agreements. Second, the Appellate Body views WTO law as a coherent legal system that emanates from a community of Members, and which is therefore simultaneously closed to renegotiation beyond the strict scope within which this community permits it and open to normative developments that carry the imprint of the community, be it within WTO organs that decide on the basis of consensus or outside WTO organs, through treaties, non-binding agreements and documents that have a credible claim to being the product of broad consensus within the international community.

While these two interpretative moves have shielded the Appellate Body, and the WTO more generally, from contestations to their legitimacy by external agents, they - together with the consequent centralization of interpretations in the hands of the Appellate Body - risk engendering "internal" contestation from WTO Members themselves. Some of the contestation of the centrality assumed by the Appellate Body in the development of the WTO legal system, in particular by the United States, has now reached an acute stage, with the blocking of the appointment of Appellate Body members and the consequent demise of the organ. But more contestation may be forthcoming if WTO adjudicators are faced with valuesbased trade restrictions justified on the grounds of an FTA. They may then be forced to choose between the closedness of the WTO legal system to bilateral deals, implied in the notion of communitization, and the open- 
ness to substantive developments to extent that they pursue the fulfilment of non-trade values.

These actual and potential contestations are evidence of a deeper challenge that faces international adjudicators. While the treaties providing them with jurisdiction may endow them with significant legal authority and direct them to preserve the integrity (or "security and predictability", as DSU Article 3.2 puts it) of the legal regime over which they adjudicate, international adjudication continues to take place within a broader system - the international legal order - that is characterized by decentralization, horizontality and the ability of states to enter into agreements among themselves, including the ability to change their minds with regard to what they previously found to be core principles in need of judicial protection. In these cases, adjudicators that had found themselves safely adjudicating in the name of a legal regime, or the multilateral governance system more broadly, may be confronted with the fact that their activity still takes place within the murky waters of the Westphalian international order. 